\title{
ST Segment Elevation Myocardial Infarction Due to Severe Ostial Left Main Stem Stenosis in a Patient with Syphilitic Aortitis
}

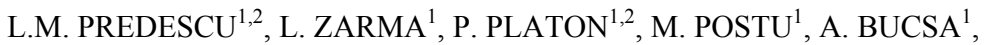 \\ M. CROITORU ${ }^{1}$, B. PRODAN ${ }^{1}$, O. CHIONCEL ${ }^{1,2}$, D. DELEANU ${ }^{1}$ \\ l"Prof. Dr. C.C. Iliescu" Emergency Institute for Cadiovascular Diseases, Bucharest \\ "“Carol Davila" University of Medicine and Pharmacy, Bucharest
}

\begin{abstract}
Cardiovascular manifestations of tertiary syphilis infections are uncommon, but represent an important cause of mortality and morbidity. Syphilitic aortitis is characterized by aortic regurgitation, dilatation of ascending aorta and ostial coronary artery lesions.

We report a case of 36 years old man admitted to our hospital for acute anterior ST segment elevation myocardial infarction complicated with cardiogenic shock (hypotension 75/50 $\mathrm{mmHg}$ ). Transthoracic echocardiography revealed a dilated left ventricle with severe systolic dysfunction (ejection fraction $=25 \%$ ), severe mitral regurgitation, moderate aortic regurgitation and mildly dilated ascending aorta. Coronary angiography showed a severe ostial lesion of left main coronary artery which was treated by urgent stent implantation and an intra-aortic contrapulsation balloon was implanted. Blood tests for syphilitic infection were positive. The patient was discharged with treatment including benzathine penicillin.

In our case, we present an acute manifestation of a syphilitic ostial left main stenosis treated by primary percutaneous coronary intervention in acute myocardial infarction. Long term follow-up of the patient is crucial as a result of potential rapid in-stent restenosis caused by continuous infection of the ascending aorta.

This case is particular because it shows that syphilitic aortitis can be diagnosed in acute settings, like ST segment elevation myocardial infarction.
\end{abstract}

Key words: Myocardial infarction, Left main stem stenosis, Syphilitic aortitis.

\section{INTRODUCTION}

Cardiovascular abnormalities are well-known manifestations of tertiary syphilis infections which although not frequent, are still a cause of morbidity and mortality. A less common manifestation of syphilitic aortitis is coronary artery ostial narrowing related to aortic wall thickening. In rare cases, this kind of coronary lesions lead to myocardial infarction [1].

\section{CASE REPORT}

We report the case of a 36 years old male patient admitted to our institute for anterior ST segment elevation myocardial infarction (STEMI) at 20 hours from the onset of chest pain, complicated with cardiogenic shock. At presentation the patient still has severe angina. Clinical examination revealed sign of peripheral hypoperfusion, cold extremities, protodiastolic gallop, systolic heart murmur at the apex, blood pressure $=75$ / $50 \mathrm{mmHg}$ under dobutamine and dopamine, heart rate $=150$ bpmin, fine crackles heard at the lung bases and oxygen saturation level of $85 \%$ without oxygen supplementation. The electrocardiogram showed sinus tachycardia, heart rate $=150 \mathrm{bpmin}$, ST segment elevation in precordial leads with biphasic T waves and ST segment elevation of 1 $\mathrm{mm}$ in aVR (Figure 1). The abnormalities of blood tests at presentation were: elevated levels of NTproBNP $(24654 \mathrm{pg} / \mathrm{mL})$, lactic acid $(4.7 \mathrm{mmol} / \mathrm{L})$, and cardiac markers (troponin $=0,230 \mathrm{ng} / \mathrm{mL}, \mathrm{CK}=$ $444 \mathrm{U} / \mathrm{L}, \mathrm{CK}-\mathrm{MB}=85 \mathrm{U} / \mathrm{L}$ ). Transthoracic echocardiography revealed a severe left ventricle systolic dysfunction with regional wall motion abnormalities, left ventricle ejection fraction 
(LVEF) of 25\%, akinesia of the interventricular septum, anterior and antero-lateral wall, apex and apical half of inferior wall, left ventricle and left atrium enlargement, severe mitral regurgitation, grade II aortic regurgitation, moderate tricuspid regurgitation and mild ascending aorta dilatation (44 mm).

The patient was rapidly transferred at the cath lab. Coronary angiography showed severe ostial left main stem stenosis, without other lesions on the left anterior descending artery, circumflex artery or right coronary artery (Figures 2, 3). Primary percutaneous coronary intervention - PCI was done. A $4.0 \times 14 \mathrm{~mm}$ bare metal stent was implanted in the left main stem (drug eluting stents were not available at that time in our institute for STEMI patients) and the stent was further post dilated with a $4.5 \mathrm{~mm}$ noncompliant balloon. The final result was very good with good stent expansion and lesion coverage and a TIMI grade 3 flow (Figure 4). At the end of the procedure an aortography was done that showed an enlarged ascending aorta with a mild aortic regurgitation (Figure 5). An intraaortic balloon pump (IABP) was inserted.

Early hemodynamic stability was achieved using the intra-aortic balloon pump which was removed after 3 days, a vasopressor (noradrenaline) and inotropic agent (dobutamine), which were down titrated and stopped after 5 days. Blood tests showed a decrease in the level of NT-pro BNP $(1496 \mathrm{pg} / \mathrm{mL})$ and a peak T troponin of $10.9 \mathrm{pg} / \mathrm{mL}$.
The clinical evolution was good with the remission of ST segment elevation on the electrocardiogram (Figure 6) and the improvement in LVEF to $35 \%$. The patient was discharged after 1 week.

At this point some questions raised about the aetiology of the severe ostial left main stem stenosis responsible for the myocardial infarction. Putting together all clinical and paraclinical data like: mild dilatation of the ascending aorta, mild aortic regurgitation, severe ostial left main stem stenosis, the absence of other lesions on coronary arteries, in a young patient (36 years old) without cardiovascular risk factors, the suspicion of syphilis raised. The diagnosis of syphilis was confirmed using a nonspecific (rapid plasma reagin) and a specific treponemal test (treponema pallidum haemagglutination assay) that were both positive. So the final diagnosis was tertiary syphilis with syphilitic aortitis complicated with anterior STEMI.

The treatment of the patient included: a beta blocker up titrated during hospital stay to the target dose (metoprolol $200 \mathrm{mg}$ /day), dual antiplatelet therapy (aspirin $75 \mathrm{mg} /$ day and clopidogrel $75 \mathrm{mg}$ /day), an angiotensin-converting-enzyme inhibitor titrated according to the blood pressure (ramipril $5 \mathrm{mg} /$ day), a mineralocorticoid receptor antagonist (spironolactone $50 \mathrm{mg} /$ day), a diuretic agent (furosemid $40 \mathrm{mg} /$ day), a statin (atorvastatin $80 \mathrm{mg} /$ day) and benzathine penicillin according to the recommendation of the infectionist.

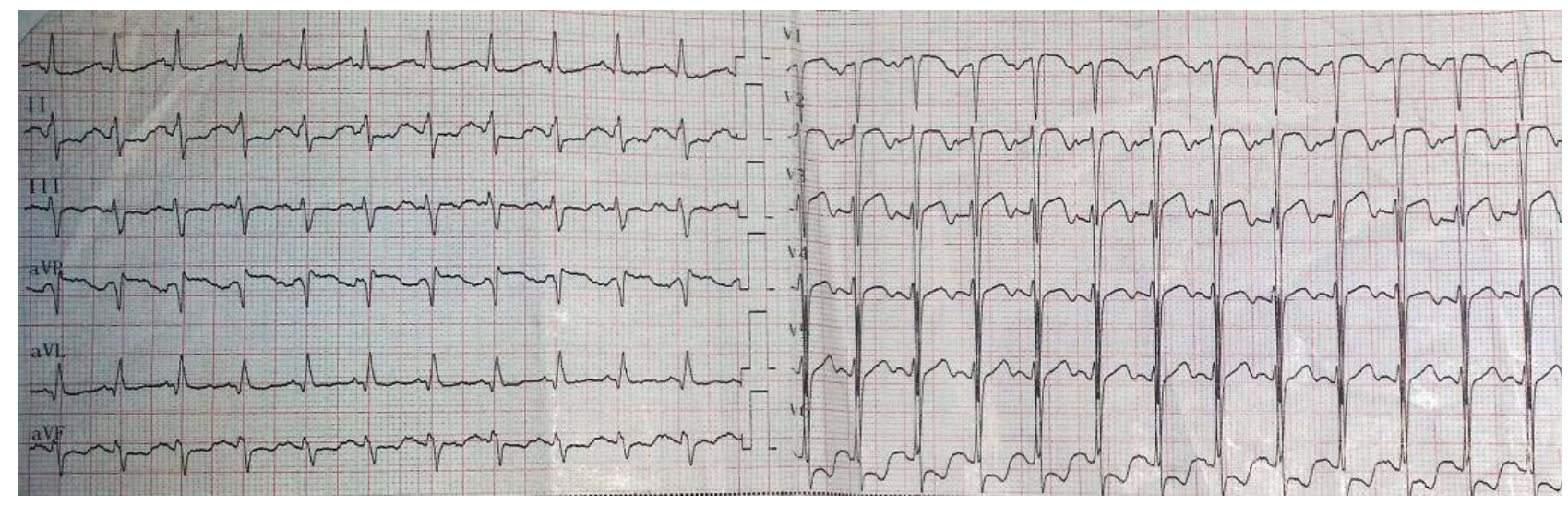

Figure 1. Electrocardiogram at admission: sinus tachycardia, heart rate $=150 \mathrm{bpmin}, \mathrm{ST}$ segment elevation in precordial leads with biphasic T waves and ST segment elevation of $1 \mathrm{~mm}$ in aVR. 


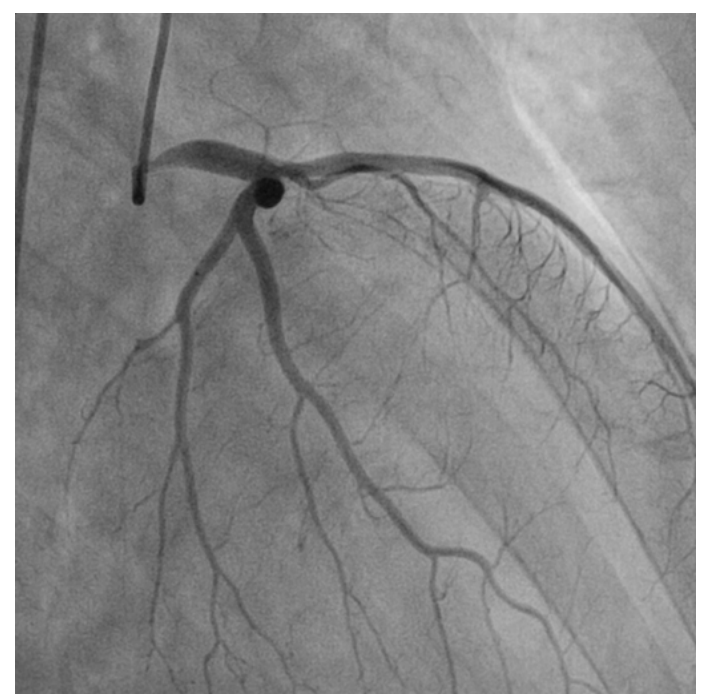

Figure 2. Coronary angiography - left coronary artery: severe ostial left main stem stenosis without other lesions on the left anterior descending artery or circumflex artery.

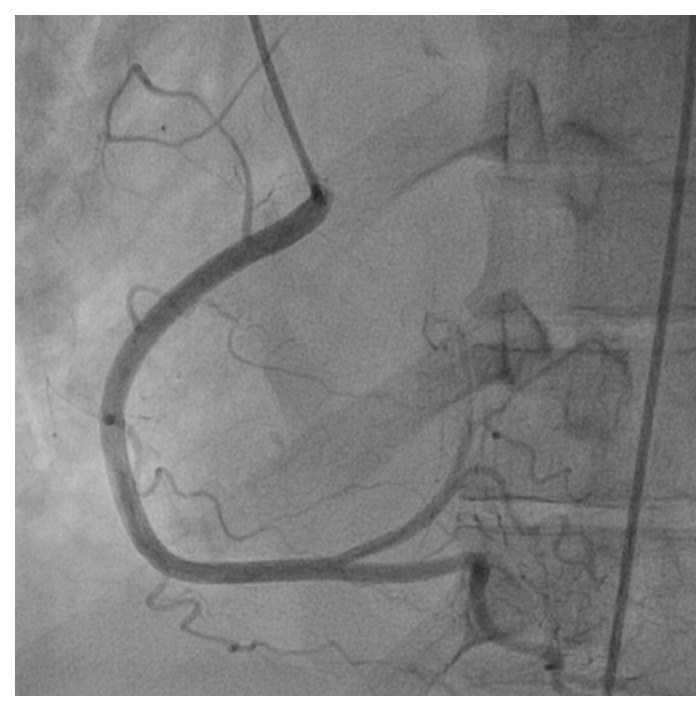

Figure 3. Coronary angiography - right coronary artery: without lesions.

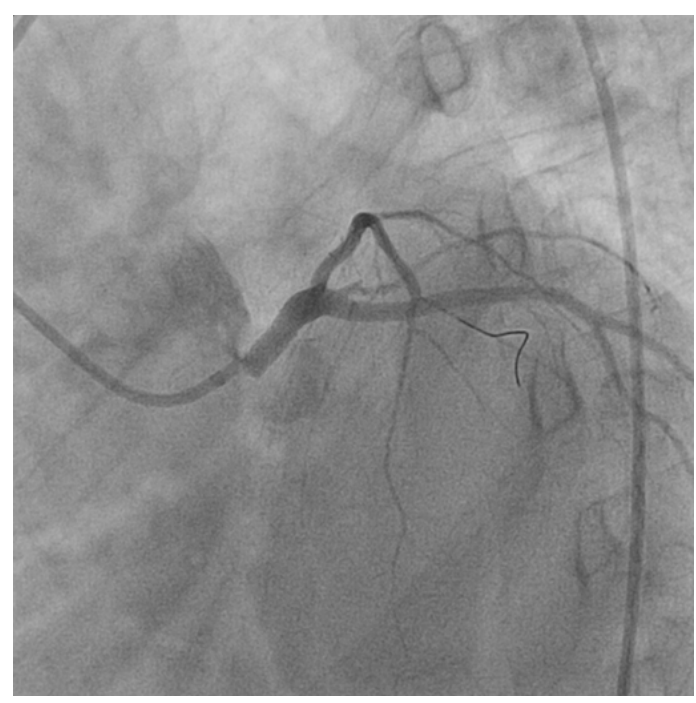

Figure 4. Final result after primary percutaneous coronary intervention (implantation of a $4.0 \times 14 \mathrm{~mm}$ bare metal stent in the left main stem post dilated with a $4.5 \mathrm{~mm}$ noncompliant balloon). 


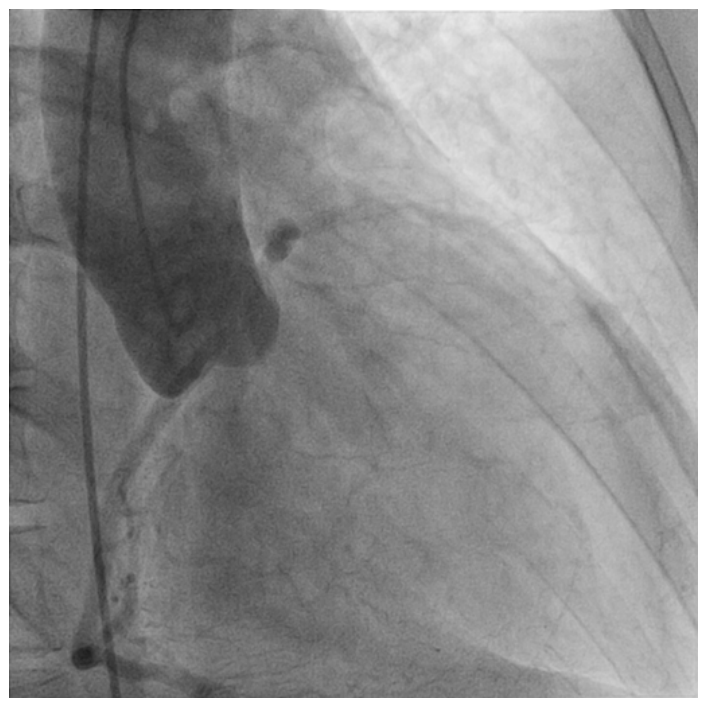

Figure 5. Aortography: mild dilatation of the ascending aorta, mild aortic regurgitation.

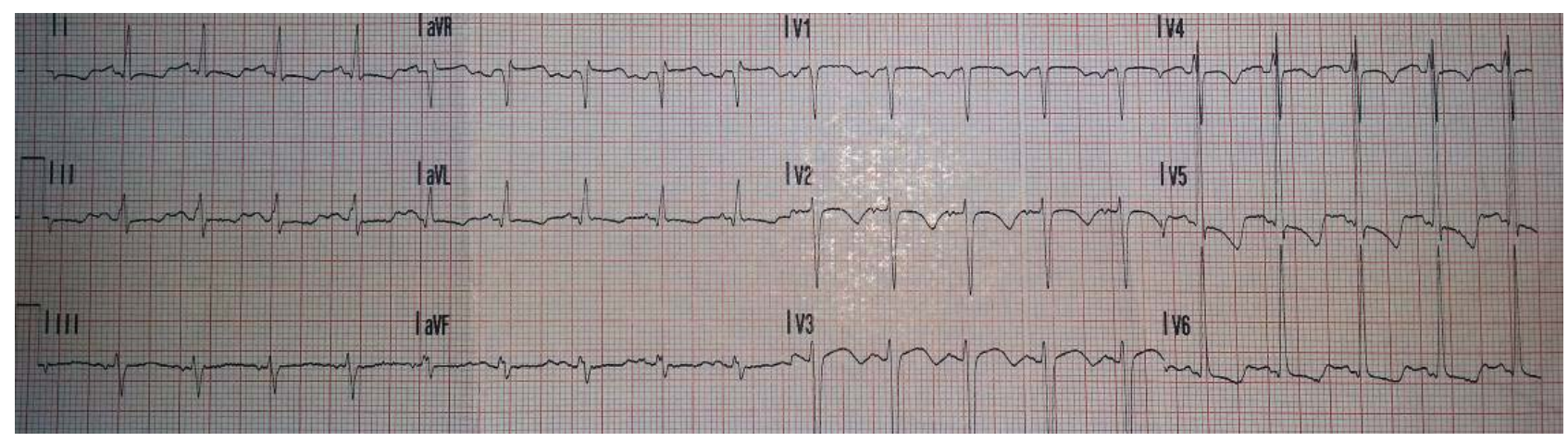

Figure 6. Electrocardiogram after the primary percutaneous coronary intervention: remission of ST segment elevation and negative $\mathrm{T}$ waves in precordial leads.

\section{DISCUSSION}

There are some aspects about the management of the case that deserve further discussions. We were in front of a patient with anterior STEMI complicated with cardiogenic shock at 20 hours after the onset of chest pain. Although the patient presented after the first initial 12 hours which is a key aspect in the STEMI protocol for undergoing primary PCI, according to the 2014 European guideline on myocardial revascularization, primary PCI is indicated in all patients with STEMI and cardiogenic shock (class of recommendation I, level of evidence B) [2].

At the end of the procedure an aortography was done to assess the severity of aortic regurgitation and the possibility of IABP insertion. Because mild aortic regurgitation is not a contraindication for IABP, it was inserted to help the acute hemodynamic stabilisation of the patient.

Syphilis is an infectious disease occurring in sequential stages, remaining latent for several years and in about $30 \%$ of the untreated patients, tertiary syphilis manifests between 10 to 30 years after the primary infection [3]. The most common manifestation of tertiary syphilis are cardiovascular and neurological complications.

The diagnosis of syphilis can be done using a nonspecific (the Venereal Disease Research Laboratory test - VDRL; rapid plasma reagin) and a specific treponemal test (enzyme immunoassay test for anti-treponemal IgG; Treponema pallidum hemagglutination test - TPHA; the microhemagglutination test with Treponema pallidum antigen; the fluorescent treponemal antibody absorption test FTA-abs and the enzyme-linked immunosorbent assay).

The incidence of syphilitic aortitis is decreasing parallel with the decrease in the incidence of syphilis infection in general population $[4,5]$. Nowadays, syphilis infection is still high in minorities, like homosexuals [6]. However, the real incidence of syphilitic aortitis is not known because frequently it remains undiagnosed. A study on 100 
clinicopathological necropsy exams showed that syphilitic aortitis was clinically diagnosed in only $17 \%$ of patients [7].

The presentation of syphilitic aortitis can vary widely: asymptomatic aortitis, aortic regurgitation, aneurysm of the ascending aorta, coronary ostial stenosis [8-10]. Morphopathology studies showed syphilitic aortitis is due to the involvement of vasa vasorum of ascending aorta with medial necrosis and destruction of elastic fibers from the aortic wall [11]. Coronary arteries are involved due to the extension of the inflammatory process from the aortic wall [12]. Ostial coronary arteries involvement is seen in $26 \%$ of patients with syphilitic aortitis [7]. It can involve either right or left coronary artery or both [13]. In most patients coronary arteries, except for the ostium, have no other lesions.

The diagnosis of syphilitic aortitis must always be considered in young patients without cardiovascular risk factors, with ostial coronary lesions without other distal lesions on coronary arteries, with aortic regurgitation and dilatation of the ascending aorta.

In rare cases, syphilitic aortitis is complicated with acute myocardial infarction $[1,3]$. In this case, the patient presented with acute anterior STEMI complicated with cardiogenic shock without previous sign of coronary artery disease.

Ostial coronary lesions due to syphilitic aortitis can be treated by surgery (coronary artery bypass grafting - CABG) or by PCI, like was the case of our patient. PCI can be a safe and effective intervention in this subgroup of patients. There are no comparative studies of PCI versus $\mathrm{CABG}$ in patients with syphilitic aortitis and ostial coronary lesions.

The follow-up of the patient with syphilitic aortitis includes surveillance for the severity of enlargement of the ascending aorta, aortic regurgitation and the high risk of in stent restenosis caused by continuous inflammation of the ascending aorta.

\section{CONCLUSIONS AND IMPLICATIONS FOR CLINICAL PRACTICE}

The incidence of tertiary syphilis has declined in recent decades owing to the early recognition of the disease and the sensitivity of the pathogen to antibiotics. However, the re-emergence of syphilis in the developing world, particularly among drug abusers and the sexually promiscuous, may mean that the delayed cardiovascular and neurologic complications of late syphilis will be seen with increasing frequency.

Acknowledgments. None.

Disclosures: The authors declare that there is no conflict of interest.

Manifestările cardiovasculare ale sifilisului terțiar sunt rare, dar reprezintă o cauză importantă de morbiditate şi mortalitate. Aortita sifilitică se caracterizează prin regurgitare aortică, dilatare de aortă ascendentă şi leziuni ostiale ale arterelor coronare.

Prezentăm cazul unui pacient în vârstă de 36 de ani internat pentru infarct miocardic acut cu supradenivelare de segment $S T$ in teritoriul anterior complicat $\mathrm{cu}$ şoc cardiogen (tensiunea arterială $=75 / 50 \mathrm{mmHg}$ ). Ecocardiografia a decelat un ventricul stâng dilatat cu disfuncție sistolică severă (fracție de ejecție $=25 \%$ ), regurgitate aortică şi mitrală moderată şi dilatare uşoară de aortă ascendentă. Coronarografia a evidențiat o subocluzie ostială de trunchi comun arteră coronară stângă pentru care s-a efectuat angioplastie de urgență cu stent şi s-a montat balon de contrapulsie intraaortică. Testele efectuate au fost pozitive pentru sifilis. Pacientul a fost externat după o săptămână, tratamentul incluzându-l pe cel cu penicilină pentru infecția sifilitică.

Cazul prezentat evidențiază o manifestare acută a unei leziuni ostiale de trunchi comun apărută în contextul unei aortite sifilitice tratată prin intervenție coronariană percutană primară. Urmărirea pe termen lung rămâne un element crucial datorită riscului de restenoză rapidă intrastent în contextul infecției continue a aortei ascendente. 
Acest caz este particular prin faptul că arată că aortita sifilitică poate fi diagnosticată în contextul unei manifestări acute, precum infarctul miocardic.

Corresponding author: Lucian M. Predescu, MD, PhD student “Carol Davila” University of Medicine and Pharmacy, Bucharest "Prof. Dr. C.C. Iliescu" Emergency Institute for Cadiovascular Diseases, Fundeni Street, no. 258, sector 2, 022328, Bucharest, Romania, Phone: +40727588031 E-mail: lucianpredescu@gmail.com

\section{REFERENCES}

1. NAKAZONE MA, MACHADO MN, BARBOSA RB, SANTOS MA, MAIA LN. Syphilitic coronary artery ostial stenosis resulting in acute myocardial infarction treated by percutaneous coronary intervention. Case reports in medicine 2010; 2010:830583.

2. AUTHORS/TASK FORCE M, WINDECKER S, KOLH P, et al. 2014 ESC/EACTS Guidelines on myocardial revascularization: The Task Force on Myocardial Revascularization of the European Society of Cardiology (ESC) and the European Association for Cardio-Thoracic Surgery (EACTS) Developed with the special contribution of the European Association of Percutaneous Cardiovascular Interventions (EAPCI). European heart journal 2014; 35:2541-619.

3. MACHADO MN, TRINDADE PF, MIRANDA RC, MAIA LN. [Bilateral ostial coronary lesion in cardiovascular syphilis: case report]. Revista brasileira de cirurgia cardiovascular : orgao oficial da Sociedade Brasileira de Cirurgia Cardiovascular 2008; 23:129-31.

4. LEFEBVRE M, BIRON C, GUILLOUZOUIC A, et al. [Syphilis in Nantes tertiary care hospital between 2000 and $2010:$ a case series of 36 hospitalized patients]. La Revue de medecine interne / fondee par la Societe nationale francaise de medecine interne 2013; 34:522-7.

5. PUGH PJ, GRECH ED. Images in clinical medicine. Syphilitic aortitis. The New England journal of medicine 2002; $346: 676$.

6. PETERMAN TA, SU J, BERNSTEIN KT, WEINSTOCK H. Syphilis in the United States: on the rise? Expert review of antiinfective therapy 2015;13:161-8.

7. HEGGTVEIT HA. SYPHILITIC AORTITIS. A Clinicopathologic Autopsy Study of 100 Cases, 1950 to 1960. Circulation 1964; 29:346-55.

8. JACKMAN JD, JR., RADOLF JD. Cardiovascular syphilis. The American journal of medicine 1989; 87:425-33.

9. CARNEIRO RC, LION MF, OLIVEIRA PR, SAN JUAN S. [Syphilitic coronary ostial obstruction]. Arquivos brasileiros de cardiologia 1976; 29:235-9.

10. LANJEWAR C, KERKAR P, VAIDEESWAR P, PANDIT S. Isolated bilateral coronary ostial stenosis - an uncommon presentation of aortoarteritis. International Journal of Cardiology 2007; 114:e126-8.

11. TONG SY, HAQQANI H, STREET AC. A pox on the heart: five cases of cardiovascular syphilis. The Medical Journal of Australia 2006; 184:241-3.

12. DARABIAN S, AMIRZADEGAN AR, SADEGHIAN H, SADEGHIAN S, ABBASI A, RAEESI M. Ostial lesions of left main and right coronary arteries: demographic and angiographic features. Angiology 2008; 59:682-7.

13. CHENG Z ZS, BI W, WANG X. Bilateral coronary ostial stenosis secondary to syphilitic aortitis. J Cardiovasc Comput Tomogr 2014 Jul-Aug; 8(4):331-3.

Received July 6, 2015 